\title{
Double pyramidal lobe at one thyroid lobe: a rare scintigraphic appearance
}

\author{
Aylin Akbulut*, F Nur Aydinbelge, Gokhan Koca, Suleyman Kalayci and Meliha Korkmaz \\ University of Health Sciences, Ankara Training and Research Hospital, Department of Nuclear Medicine, Ankara, Turkey
}

\begin{abstract}
The thyroid gland may show anatomical variations related to embryonic developmental stages. Persistence of the thyroglossal duct is the cause of most variations in the thyroid gland, which are seen as cyst or ectopic thyroid tissue formation and the pyramidal lobe. The presented case is a patient with Graves' disease showing two pyramidal lobes at the right lobe of the thyroid gland, which is extremely rare on presentation.
\end{abstract}

\section{Case report}

A 70-year old female patient was referred to the nuclear medicine clinic because of a history of hyperthyroidism symptoms of increasing tremors, palpitation and tiredness. She had a history of thyroid complaints unresponsive to medical treatment. The laboratory test results were sT3: 5.95 (normal range $2.3-4.2 \mathrm{pg} / \mathrm{mL}$ ), sT4: $3.74 \mathrm{ng} / \mathrm{dL}$ (normal range: $0.58-1.25$ ) and $\mathrm{TSH}<0.003 \mu \mathrm{IU} / \mathrm{mL}$ (normal range: 0.38-5.33) which were consistent with hyperthyroidism.

Thyroid scintigraphy with ${ }^{99 m} \mathrm{Tc}$-pertechnetate was performed to diagnose the cause of hyperthyroidism. The scintigraphic findings were compatible with Graves' disease and also showing the presence of two pyramidal lobes in the right lobe of the thyroid gland; one is extending superiorly at the upper pole and the other is extending inferiorly in the bottom pole on thyroid scintigraphy (Figure 1). Ultrasonography (USG) showed diffusely heterogeneous, hypoechogenic and increased vascularity parenchyma on the thyroid gland concordant with Graves' disease and confirmed superior and inferior pyramidal lobes rising from the same lobe of the thyroid gland (Figure 2).

\section{Discussion}

The pyramidal lobe is the most common variation of these and an embryologic remnant of the caudal end of the thyroglossal duct $[1,2]$. The prevalence of that has been reported to $12 \%-65 \%[3,4]$. On thyroid

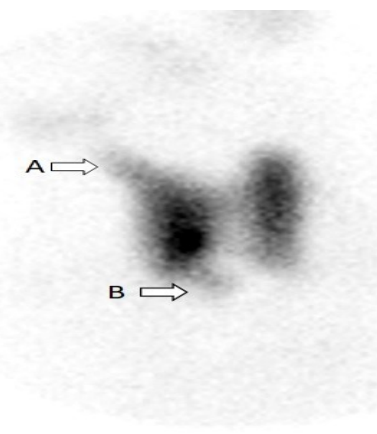

Figure 1. Thyroid scintigraphy showing diffuse radioactivity uptake compatible with Graves' disease. Arrow A is showing the superior pyramidal lobe and arrow B is showing the inferior pyramidal lobe of the right lobe of the thyroid gland on thyroid scintigraphy.

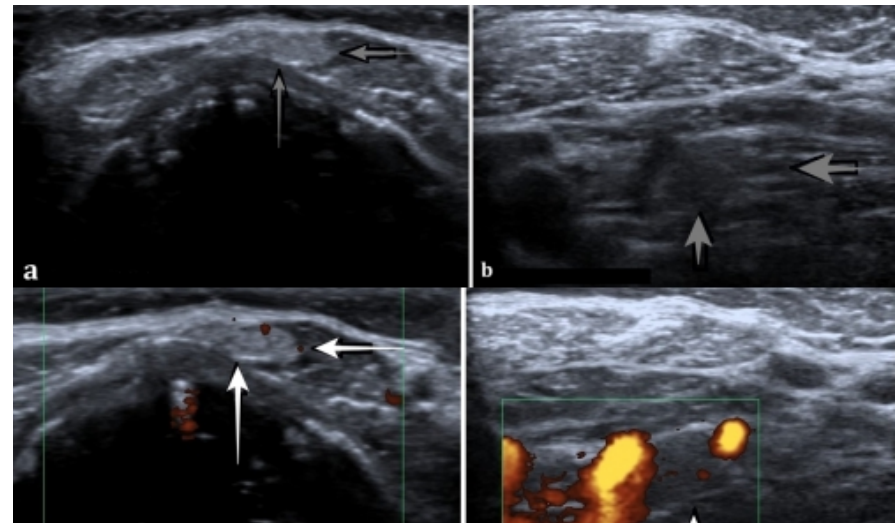

Figure 2. Gray long arrows showing ultrasonography (USG) images of superior (a) and gray short arrows for inferior (b) pyramidal lobes in the right lobe of the thyroid gland; doppler USG images showing the vascularity of superior (c) pyramidal lobe with long white arrows and inferior (d) pyramidal lobes with thick white arrow

scintigraphy, the anatomic origin of the pyramidal lobe has been shown to arise from the right side in $43.7 \%$, from the left in $46.7 \%$ and from the isthmus in $9.5 \%$ [5].

The treatment options for Graves' disease are antithyroid drug, radioiodine and thyroid gland surgery. Thyroid gland surgery is one of the more common surgical interventions in the head and neck region. The principle of safe and effective thyroid surgery is to understand and observe the anatomy of the thyroid gland and its possible variations.

The pyramidal lobe is usually visualized when there is significant stimulation as hyperthyroidism [6]. All thyroid diseases may originate

${ }^{\star}$ Correspondence to: Aylin Akbulut MD, Department of Nuclear Medicine, University of Health Sciences, Ankara Application and Research Hospital, Ulucanlar Street, 06340 Ankara, Turkey, Tel: +90 5336461631; Fax: +90 312595 38 56; E-mail: aylinbaskin@gmail.com

Key words: pyramidal lobe, thyroid gland, thyroid scintigraphy, Graves' disease

Received: March 13, 2018; Accepted: March 23, 2018; Published: March 31, 2018 
from that $[7,8]$. It is of importance in treatment planning for thyroid disease. It is especially important to know the localization and number of that in the patient who will undergo a total thyroidectomy operation because after surgery there is known to be a high risk of disease recurrence. Therefore, it should be examined before thyroid surgery.

\section{Conflict of interest}

Author hereby declares that he has no financial disclosures and acknowledging any financial support.

\section{References}

1. Ignjatovic M (2009) Double pyramidal thyroid lobe. J Postgrad Med 55: 41-42. [Crossref]

2. Hakeem AH, Hakeem IH, Wani FJ (2016) Double pyramidal lobe of thyroid gland: A rare presentation. Thyroid Research and Practice 13: 25.
3. Braun EM, Windisch G, Wolf G, Hausleitner L, Anderhuber F (2007) The pyramidal lobe: clinical anatomy and its importance in thyroid surgery. Surg Radiol Anat 29: 2127. [Crossref]

4. Zivic R, Radovanovic D, Vekic B, Markovic I, Dzodic R, et al. (2011) Surgical anatomy of the pyramidal lobe and its significance in thyroid surgery. S Afr J Surg 49: 110-116. [Crossref]

5. Türkölmez S, Çayır D, Korkmaz M, Demirel K, Koca G (2007) Detection rate of pyramidal lobe on thyroid scintigraphies and its frequency in different thyroid pathologies. Gülhane Tip Dergisi 49: 32-35

6. Shinto A, Bandopadhyay A, Selvakumar J (2009) Graves disease with midline ectopic and bifid pyramidal lobes on pertechnetate thyroid scintigraphy. Clin Nucl Med 34: 31-32. [Crossref]

7. Ogawa C, Kammori M, Onose H, Yamada E, Shimizu K, et al. (2009) Follicular carcinoma arising from the pyramidal lobe of the thyroid. J Nippon Med Sch 76: 169172. [Crossref]

8. Sternberg JL (1986) Sublingual Pyramidal Lobe: Complications of Subtotal Thyroidectomy for Graves' Disease. Clin Nucl Med 11: 766-768. [Crossref]

Copyright: $\mathbb{C} 2018$ Akbulut A. This is an open-access article distributed under the terms of the Creative Commons Attribution License, which permits unrestricted use, distribution, and reproduction in any medium, provided the original author and source are credited. 